\title{
Evolution and Driving Forces of Non-Point Source Pollution in a Developing Megacity: Beijing as a Long-Term Case Study
}

\author{
Hezhen Lou ${ }^{1}$, Shengtian Yang ${ }^{1 *}$, Fanghua Hao ${ }^{1}$, Xiaoyu Ren ${ }^{2}$, Changsen Zhao ${ }^{1}$, \\ Yue Wang ${ }^{3}$, Tianjie Lei ${ }^{4}$, Feng Sun ${ }^{5}$ \\ ${ }^{1}$ College of Water Sciences, Beijing Normal University, Beijing Key Laboratory for Remote \\ Sensing of Environment and Digital Cities, Beijing, China \\ ${ }^{2}$ Beijing Weather Modification Office, Beijing, China \\ ${ }^{3}$ School of Biological Science, Georgia Institute of Technology, Atlanta, Georgia, USA \\ ${ }^{4}$ China Institute of Water Resources and Hydropower Research (IWHR), Beijing, China \\ ${ }^{5}$ Beijing Hydrological Center, Haidian District, Beijing, China
}

Received: 15 October 2018

Accepted: 25 November 2018

\begin{abstract}
Nonpoint source pollution (NPSP) is a serious environmental problem faced by megacities throughout the world. Unlike small cities, problems associated with NPSP are more complex in developing megacities. However, long-term spatial and temporal variations in NPSP, as well as the driving forces behind these changes, are still unknown for a developing megacity. In this study, we used a model set containing export coefficients and statistical models to calculate NPSP load for five NPSP types from 2006 to 2016 in Beijing and its four city functional zones. Our results indicate that the total NPSP decreased by $8.1 \%$ from 2006 to 2016. Agricultural NPSP was the largest source of NPSP and measured $46.2 \%$ in 2016. Agricultural NPSP, livestock NPSP and soil erosion NPSP decreased by $19.1 \%, 38.7 \%$, and $0.8 \%$. However, urban NPSP and rural NPSP increased by $10.8 \%$ and $8.5 \%$. In the four functional zones, urban NPSP in the capital function core zone decreased by $17.3 \%$, total NPSP in the urban functional development zone increased by $43.0 \%$, total NPSP in the urban development fresh zone decreased by $13.1 \%$ and total NPSP in the ecological conservation development zone decreased by $14.7 \%$. The urban functional development zone was key to preventing future NPSP.
\end{abstract}

Keywords: NPSP, developing megacity, spatial and temporal variation, driving forces, remote sensing

*e-mail: yangshengtian@bnu.edu.cn 


\section{Introduction}

Nonpoint source pollution (NPSP) is a serious environmental problem not only in agricultural regions but in urban regions throughout the world. NPSP degrades vital water resources and deprives natural systems and their component species [1-2]. NPSP has been categorized into many types based on specific pollution sources, including agricultural NPSP [3-4], urban NPSP [5], livestock NPSP [6-7], rural NPSP [8], and soil erosion NPSP [9]. Agricultural NPSP and urban NPSP have been given more attention because they have a direct and significant impact on environmental quality, human health, and urban planning [10-11]. Compared with agricultural NPSP, urban NPSP has a longer research history that extends back to the 1972 Federal Water Pollution Control Act [12], but due to its unique characteristics it has a slower rate of improvement relative to agricultural NPSP.

Urban NPSP has three significant features: complex components, a correlation with human activities and a susceptibility to policy and urban planning. Unlike agricultural NPSP, which is primarily concerned with nitrogen and phosphorus [13-14], urban NPSP contains very complex components that may include COD (chemical oxygen demand), BOD (biochemical oxygen demand), nitrogen $\left(\mathrm{NH}_{4}, \mathrm{NO}_{3}\right.$ and total nitrogen), and phosphorus (dissolved phosphorus, total phosphorus) [15-16]. This complexity is the result of two factors. First, urban areas contain more pollution sources, such as artificial waste, and these components are very unpredictable. Second, the land use and land cover is very complex and may include dozens of land use types particular to a megacity [17]. In addition, human activity is more strongly correlated with urban NPSP relative to agricultural NPSP. Urban NPSP loads are influenced by human activities such as construction, city sanitation and public traffic. At the same time, human experiences are influenced by NPSP pollution, as in the case of city river eutrophication [18]. Urban NPSP is also influenced by policy and urban planning because of strong relationships with residents. For example, it can be influenced by changes in policy (e.g., environmental act) and urban planning (e.g., urban planning for the Olympic Games). Policy and planning have the ability to change the NPSP load over the short-term.

Previous research regarding urban NPSP has focused on the driving forces behind spatial and temporal variations in small cities and communities and in the short-term (i.e., rainfall events). However, the driving forces behind spatial and temporal variations in NPSP over the long-term, and for a developing megacity, are unclear. Ventura and Kim (1993) [19] modeled urban nonpoint source pollution in a $12.4 \mathrm{~km}^{2}$ area in Dodge County, Wisconsin. Tsihrintzis and Hamid (1998) calculated NPSP in four relatively small urban sites (5.97-23.56 ha) in southern Florida. Mitchell (2005) [20] calculated the urban watershed NPSP in the Aire basin, Yorkshire, U.K., to be $2,057 \mathrm{~km}^{2}$. Chen et al. (2008)
[8] calculated NPSP for a $42 \mathrm{~km}^{2}$ urban-rural area in Hangzhou city, China. Ping et al. (2013) [21] simulated NPSP in Minyun County, located in Beijing, in a $1010 \mathrm{~km}^{2}$ area.

It is difficult to obtain information of NPSP from a single method owing to there being multiple NPSP types. Statistical models, export coefficients models, semi-mechanism models, and mechanism models have been frequently used to obtain the urban NPSP. Statistical models have been used to build relationships between NPSP load and land surface information or runoff, such as the PARROW model [22-23]. Coefficient models have been used to describe the mass pollutant load delivered to the stream edge for a particular land use. The models were based on empirical studies of transit loss and measurements of nutrient loads [24]. Semi-mechanism models integrate empirical and mechanism models, such as SWMM [25]. Mechanism models, such as the BASINS model [26], are based on the physical and chemical mechanism of generation and cycle. Semi-mechanism models and mechanism models need rigorous input data, thus these two models have been used for the small city or community scale. For the megacity scale, simple statistical models and coefficient models offer advantages in data preparation. Statistical models require less data compared with mechanical models, which is crucial given that data collection in megacities is difficult.

The objectives of this paper are to obtain the multiNPSP types from 2006 to 2016 for Beijing by using an NPSP model set of export coefficients and statistical models, address spatial and temporal variations in NPSP over the long-term for a megacity and examine the driving forces behind spatial and temporal variations in NPSP. In this paper, the study area and the calculation method for NPSP are described, the NPSP results for the two periods and their spatial distribution are presented, and the driving forces are discussed based on detailed surveys and statistical data.

\section{Material and Methods}

\section{Study Domain}

Beijing is a megacity that serves as the capital of China. It has an area of $16,807.8 \mathrm{~km}^{2}$ and is located within $39.4-41.6^{\circ} \mathrm{N}, 115.7-117.4^{\circ} \mathrm{E}$ (Fig. 1). Beijing is located in a temperate climatic zone with mean annual temperature of $12^{\circ} \mathrm{C}$ and annual average precipitation of $640 \mathrm{~mm}$. Beijing is located in the northern part of the northern China plain [27], which includes 16 districts and counties (Fig. 1). Topographically, Beijing is characterized by mountains in the northwest, which account for $62 \%$ of the total area, and the "Beijing Plain" in the southeast, which accounts for $38 \%$ of the total area; the elevation is lower than $100 \mathrm{~m}$ [28]. Though more than 200 rivers flow through this city, water depletion is a continuous problem because it is 
located in a semi-arid area with large water demand. Natural vegetation in this area is deciduous broadleaf forest (e.g., Populustomentosa, Betulaplatyphylla), evergreen coniferous forest (e.g., Pinustabulaeformis, Quercusacutissima), and bush grass. However, most of the original natural vegetation has been removed due to human activity and urban development.

Over the past few decades, Beijing has experienced rapid urbanization and further encroachment into the surrounding countryside. In 2016, Beijing had a population of 21.7 million with an average population density of 1,324 persons $/ \mathrm{km}^{2}$ [29]. Because of rapid urban expansion and population growth, Beijing has experienced intensive land-use changes from natural land to construction land [30]. In 2012, the total area of Beijing was divided into four functional zones (Fig. 1). The capital functional zone (Dongcheng District and Xicheng District) played the role of capital. The urban functional development zone (Haidian District, Shijingshan District, Fengtai District, Chaoyang District) played the role of financial and international exchange. The urban development fresh zone (Fangshan District, Tongzhou District, Shunyi District, Changping District, Daxing District) played the role of manufacturing and modern agriculture. The ecological conservation development zone (Yanqing District, Miyun District, Mentougou District, Huairou District, Pinggu District) provided an ecological barrier for Beijing (Fig. 1).

\section{Algorithms of NPSP Calculation}

Due to Beijing's large area and complex urban components, NPSP were classified into five types, including rural NPSP, agricultural NPSP, livestock NPSP, soil erosion NPSP, and urban NPSP. These five NPSP types were the main nonpoint source pollution types for Beijing. We focused on the four leading contaminants associated with NPSP pollution, including COD (chemical oxygen demand), $\mathrm{NH}_{4}, \mathrm{TN}$ (total nitrogen), and TP (total phosphorus).

In this study, an NPSP model set of export coefficient models [31-32], and statistical models [33] was used to calculate the five NPSP loads for Beijing. The function details used in this study are displayed in Table 1. There are two reasons for using a model set instead of one model. First, diverse NPSP types not only include traditional urban NPSP but also cover agricultural NPSP; complex land surface conditions and a large population make it difficult to calculate NPSP load in just one model. Second, complex physical models like the SWMM model [34] are often used to calculate the urban NPSP, but it can be difficult to collect input data to satisfy the model completely in the long term. For example, it is not possible to obtain the pipeline data for Beijing because of legal restrictions.

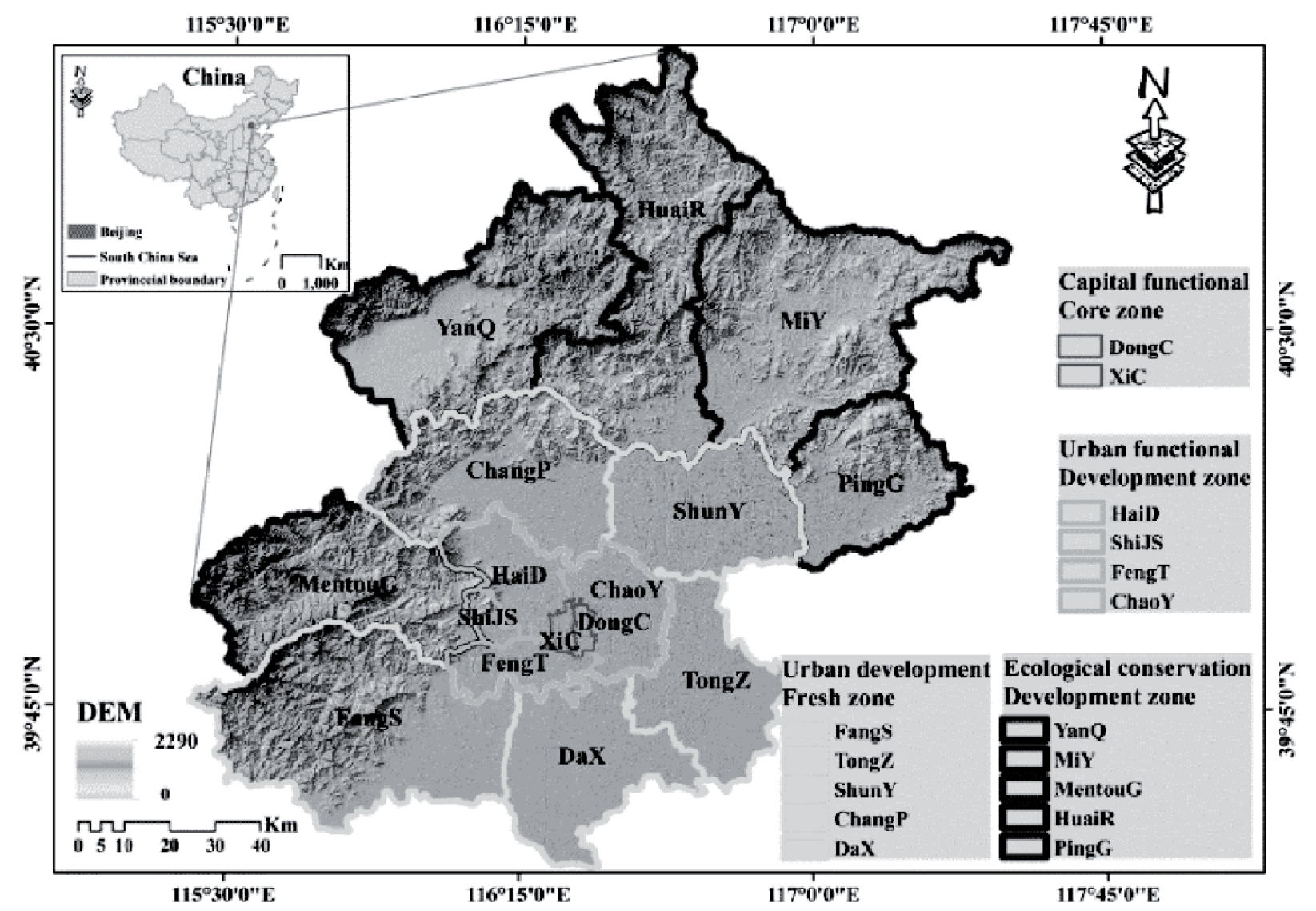

Fig. 1. Study area showing the topography of Beijing and the four functional zones. 
Table 1. NPSP model set and functions used in this study.

\begin{tabular}{|c|c|c|c|}
\hline Number & NPSP module & Functions & References \\
\hline 1 & $\begin{array}{l}\text { Rural NPSP } \\
\text { Agricultural NPSP } \\
\text { Livestock NPSP }\end{array}$ & $\begin{array}{c}L=\sum_{i=1}^{n} \alpha \beta E_{i}\left[A_{i}\left(I_{i}\right)\right]+p \\
\alpha=\alpha_{t} \cdot \alpha_{s}=\frac{R_{i} \cdot R_{j}}{\bar{R} \cdot \bar{R}} \\
\beta=\frac{L\left(\theta_{j}\right)}{L(\bar{\theta})}=\frac{c \theta_{j}^{d}}{c \bar{\theta}^{d}}=\frac{\theta_{j}^{d}}{\bar{\theta}^{d}} \\
E_{h}=D_{a} \times H \times 365 \times M \times B \times R_{S} \times C \\
p=c \times a \times Q \\
L=c \theta^{d}\end{array}$ & [31-33] \\
\hline \multirow[t]{2}{*}{2} & Soil erosion NPSP & $\omega=\sum \omega_{i} \times A_{i} \times E R_{i} \times c_{i} \times 10^{-6}$ & {$[33]$} \\
\hline & & $\begin{array}{l}\omega_{i}=11.8\left(\mathrm{Q}_{\text {surf }} \mathrm{q}_{\text {peak }} \text { area }_{\text {pixel }}\right)^{0.56} \\
K C L S C F R G\end{array}$ & [33] \\
\hline 3 & Urban NPSP & $L=R \times C_{N P S} \times A \times 10^{-6}$ & {$[32]$} \\
\hline
\end{tabular}

Annotations: $L$ : amount of NPSP load (t), $\alpha$ : rainfall influence factor, $\beta$ : topographical factor, $E_{i}$ : export coefficient, $A_{i}$ : area of land use or amount of population or livestock $\left(\mathrm{km}^{2}\right.$ or $\left.10^{4}\right), I_{i}$ : input of NPSP $(\mathrm{t}), p$ : NPSP from rainfall $(\mathrm{t}), \alpha_{i}$ : rainfall time influence factor, $\alpha_{s}$ : rainfall space distribution influence factor, $R_{i}$ : mean monthly rainfall for one space unit in $i^{\text {th }}$ month $(\mathrm{mm}), R_{i}$ : annual rainfall for the $j^{\text {th }}$ space unit $(\mathrm{mm}), \bar{R}$ : mean annual rainfall for the entire area $(\mathrm{mm}), \theta_{j}$ : slope of the $j^{\text {th }}$ space unit $\left({ }^{\circ} \mathrm{C}\right), \bar{\theta}$ : mean slope for the total area $\left({ }^{\circ} \mathrm{C}\right)$, c: constant factor, d: constant factor, $E_{h}$ : NPSP export from population per year $(\mathrm{t}), D_{c}:$ NPSP export per person in one day (t), $H$ : total population in the whole area $\left(10^{4}\right), 365$ : days in one year, $M$ : NPSP deduction by physical process $(0.85-0.9), B$ : NPSP deduction by biological process (0.8-0.9), $R$ : retention coefficient of NPSP in the filter tank (0.1-0.8), $C$ : P deduction coefficient $(0.1-0.2), c$ NPSP concentration in the rainfall $(\mathrm{mg} / \mathrm{L}), \alpha$ : rainfall in the whole area $\left(\mathrm{m}^{3}\right), Q$ : ratio of runoff and rainfall, $\omega$ : the amount of NPSP from soil erosion $(\mathrm{t}), \omega_{i}$ : soil erosion in one land-use type $\left(\mathrm{t} / \mathrm{km}^{2}\right), E R_{i}$ : enrichment factor, $c_{i}$ : the concentration of NPSP in the soil $\left(\mathrm{t} / \mathrm{km}^{2}\right)$,sed: Sediment yield on a given day $(\mathrm{t})$,Qsurf: Surface runoff volume $(\mathrm{mm})$,qpeak: Peak runoff rate $(\mathrm{m} 3 / \mathrm{s})$, area pixel: Area of the pixel $\left(\mathrm{km}^{2}\right), \mathrm{K}$ : soil erodibility factor, C: The cover and management factor, P: Support practice factor, LS: topographic factor, CFRG: coarse fragment factor, $R$ : annual runoff $(\mathrm{mm}), C_{N P S}:$ the mean concentration of NPSP in the runoff $(\mathrm{mg} / \mathrm{L})$.

\section{Results and Discussion}

\section{Temporal and Spatial Variations in NPSP from 2006 to 2016}

Five Beijing NPSP pollution loads, from 2006 to 2016, are shown in Fig. 2. From 2006 to 2016, the total NPSP amount for a single year decreased by $8.1 \%$, from $234,700 \mathrm{t}$ in 2006 to $215,709 \mathrm{t}$ in 2016. For the five types of NPSP pollution, agricultural NPSP was the dominant NPSP type. In 2006 and 2016, 52.3\% and 46.2\% of the total NPSP was agricultural NPSP, respectively. The three largest NPSP types, in order of total contribution, were agricultural NPSP $>$ urban NPSP $>$ soil erosion NPSP. In 2006, livestock NPSP was $2.0 \%$ and was higher relative to the rural NPSP. However, this reversed in 2016 with livestock NPSP measuring 1.3\%. From 2006 to 2016, agricultural NPSP, livestock NPSP and soil erosion NPSP decreased by $19.1 \%, 38.7 \%$, and $0.8 \%$, respectively; livestock NPSP has decreased considerably.
Urban NPSP and rural NPSP have increased by $10.8 \%$ and $8.5 \%$, respectively.

Four of the five NPSP types displayed variations in pollution elements from 2006 to 2016 (Fig.2). For the rural NPSP, all four elements increased from 2006 to 2016 and the increasing NPSP was largely similar year to year but reached a maximum of $8.5 \%$. For agricultural NPSP, TN was the leading element and accounted for $65.8 \%$ in 2006 and $59.2 \%$ in 2016. All four elements in agricultural NPSP declined from 2006 to 2016. TN decreased the most and reached $27.2 \%$ of the total. Livestock NPSP showed a significant decrease over the study period and COD, $\mathrm{NH}_{4}, \mathrm{TN}$ and TP decreased by $46.4 \%, 51.0 \%, 28.1 \%$ and $19.5 \%$, respectively. TN was still the main pollution element in the livestock NPSP. Soil erosion NPSP did not display obvious variations though the total amount was large. COD was the main element in soil erosion NPSP and it measured $76.7 \%$ in 2006 and $72.8 \%$ in 2016. COD and TP decreased by $5.7 \%$ and $9.8 \%$, but the $\mathrm{NH}_{4}$ and $\mathrm{TN}$ increased by $6.0 \%$ 

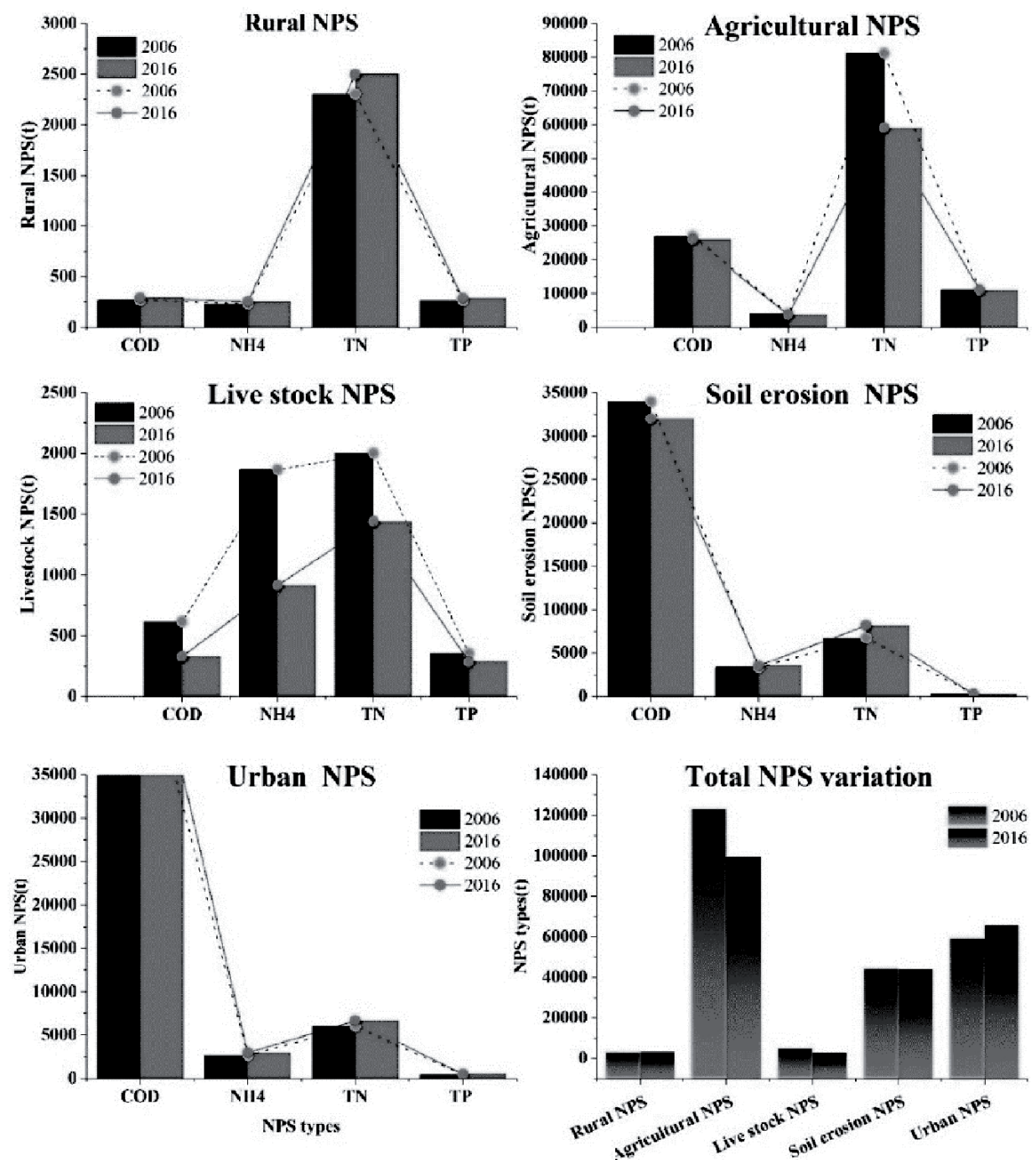

Fig. 2. Variations for the five NPSP types in Beijing from 2006 to 2016.

and $21.2 \%$. Urban NPSP increased by $10.8 \%$ over the study period. COD was the main pollution element and reached $84.6 \%$ during the study period. TP has the most increase that reached $11.1 \%$.

Spatial variations for the five NPSP types in Beijing from 2006 to 2016 are shown in Fig. 3. The NPSP spatial map was classified into 16 levels. Different NPSP types showed distinct differences in terms of spatial distribution; the distribution also varied from 2006 to 2016.

Rural NPSP is primarily located in the east-middle area of Beijing and covers the Changping District, Shunyi District, and Tongzhou District. From 2006 to 2016, rural NPSP in the two northern districts (Yanqing District and Miyun District) represented reverse variations, where NPSP in Yanqing decreased while NPSP in Miyun increased. In terms of agricultural NPSP, there was an area of high NPSP southeast of Beijing that included the Fangshan District, Daxing District, Shunyi District, and Tongzhou District. Agricultural NPSP did not vary drastically except in the
Mentougou District. There were high levels of livestock NPSP in the south plain area and north mountain area, particularly in the Mentougou District, Fangshan District, Daxing District, Shunyi District, and Miyun District. For the study period, livestock NPSP showed drastic spatial variations. Livestock NPSP decreased in the Yanqing District but increased in the Mentougou and Shunyi districts. Soil erosion NPSP primarily occurred in the north mountain area, which included the Yanqing District, Huairou District, and Miyun District. From 2006 to 2016, soil erosion NPSP decreased, especially in the north. Urban NPSP was high in the middle region, where "old Beijing" is located. Over the study period, urban NPSP increased in the middle region and in the Huairou District.

The spatial distribution of four pollution element types are shown in Fig. 4. COD showed different spatial characteristics in 2006 than in 2016. In 2006, the area of high COD was located mainly in north districts, and the total amount was large. In 2016, the area of high COD had decreased, especially in the north. Unlike COD, 


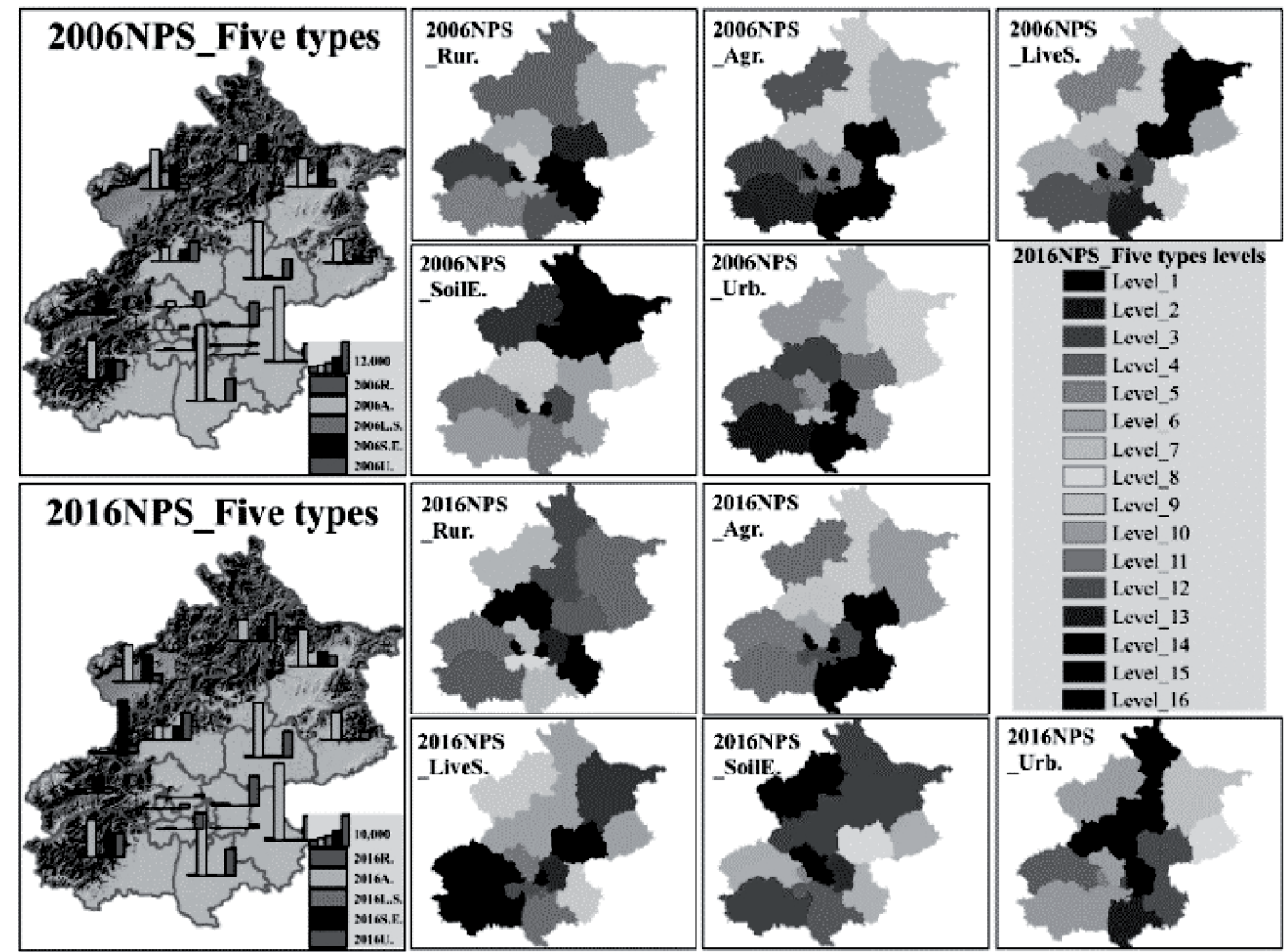

Fig. 3. Spatial variations for the five NPSP types in Beijing from 2006 to 2016.

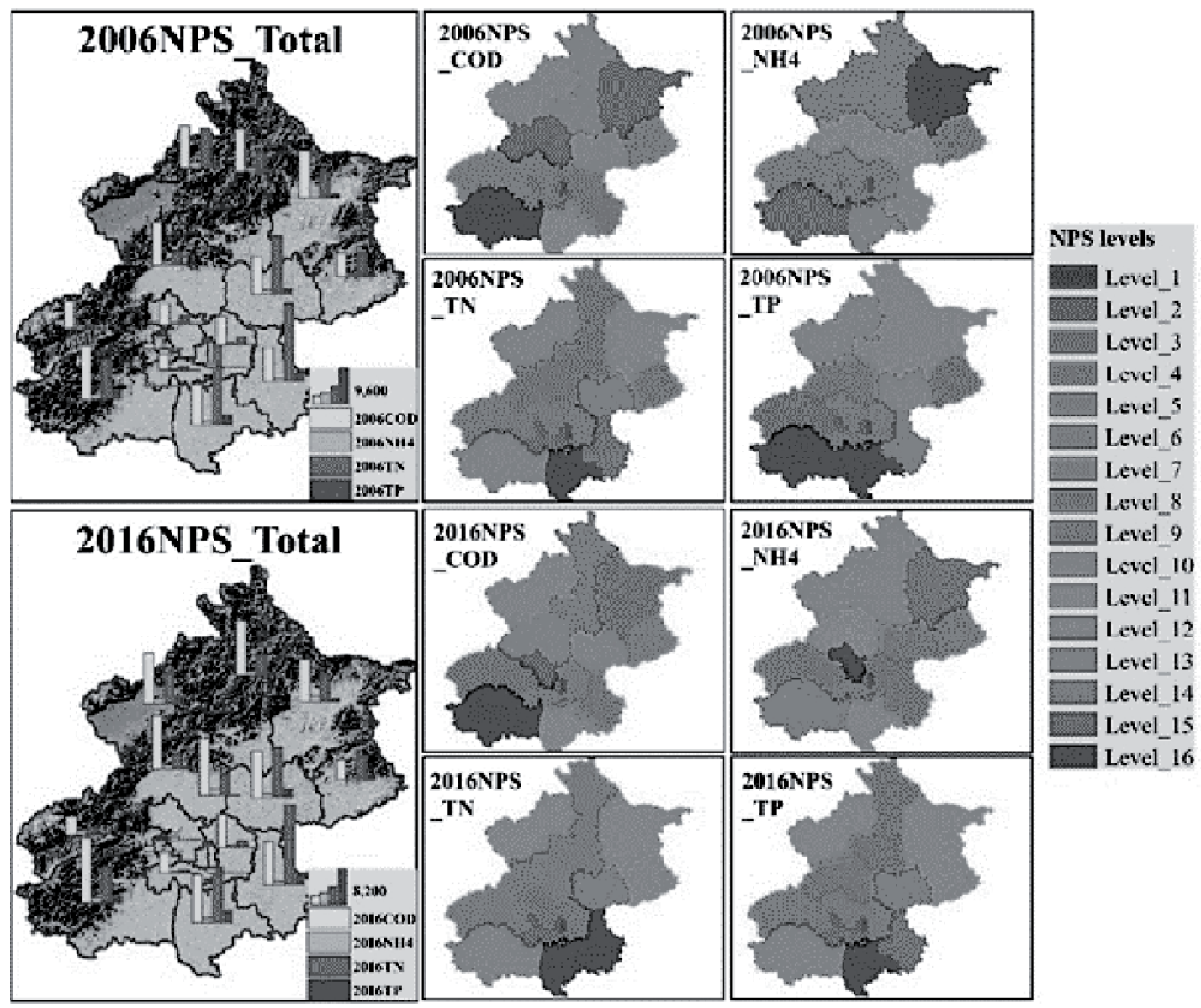

Fig. 4. Spatial variations for the four NPSP pollution elements in Beijing from 2006 to 2016. 
the spatial distribution of $\mathrm{NH}_{4}$ was similar in 2006 and 2016. Areas of high $\mathrm{NH}_{4}$ were located in the north and in the Fangshan District. In terms of TN, there was no distinct difference between 2006 and 2016 and the area of high TN was located in the south and east. In the middle of the old urban area TN declined. TP was an important element for water quality. Areas of high TP decreased mainly in the south and in the Fangshan District.

NPSP Distribution and its Element Variations in the Different Urban Function Zones

Variations in the five NPSP types for the four urban function zones are shown in Fig. 5. Different NPSP types and characters have been presented for the four urban function zones. In the capital function core zone, only the urban total NPSP load decreased (17.3\%) from 2006 to 2016. The urban functional development zone contained the five NPSP types, and total NPSP increased by $43.0 \%$. In this zone, urban NPSP was the leading type during the study period and measured $77.3 \%$ in 2006 and $46.5 \%$ in 2016. From 2006 to 2016 , rural NPSP increased by $0.9 \%$ and soil erosion NPSP increased by $22.8 \%$, but the agricultural NPSP, livestock NPSP and urban NPSP decreased by $38.0 \%$, $79.4 \%$ and $14.1 \%$, respectively. In the urban development fresh zone, the total NPSP load decreased by $13.1 \%$ from
2006 to 2016. Agricultural NPSP was the primary NPSP type and measured $64.3 \%$ in 2006 and $57.2 \%$ in 2016 . From 2006 to 2016, rural NPSP increased by $40.9 \%$ and urban NPSP increased by $8.4 \%$, while agricultural NPSP, livestock NPSP and soil erosion NPSP decreased by $22.7 \%, 50.0 \%$ and $0.2 \%$, respectively. In the ecological conservation development zone, the total NPSP load decreased by $14.7 \%$ over the study period. Agricultural NPSP and the soil erosion NPSP were consistently the primary pollution types.

Variations in the four NPSP pollution elements from 2006 to 2016 are shown in Fig. 6. The elements present vary between 2006 and 2016. In 2006, primary elements were COD and TN, which measured $47.7 \%$ and $41.8 \%$, respectively. 2016 was similar to 2006 and the primary elements were also $\mathrm{COD}$ and $\mathrm{TN}$, which measured $53.0 \%$ and $36.0 \%$, respectively. The total amounts for $\mathrm{NH}_{4}, \mathrm{TN}$ and TP decreased by $6.2 \%, 20.8 \%$ and $1.2 \%$, respectively. COD was an exception and increased by $2.0 \%$ from 2006 to 2016 .

\section{LUCC and Population Increase Indicate that Urban Development Drives NPSP}

LUCC acted as a sensitivity indicator for urban development. The variation was captured using remote sensing data from 2006 to 2016 (Fig. 7). In 2006 and

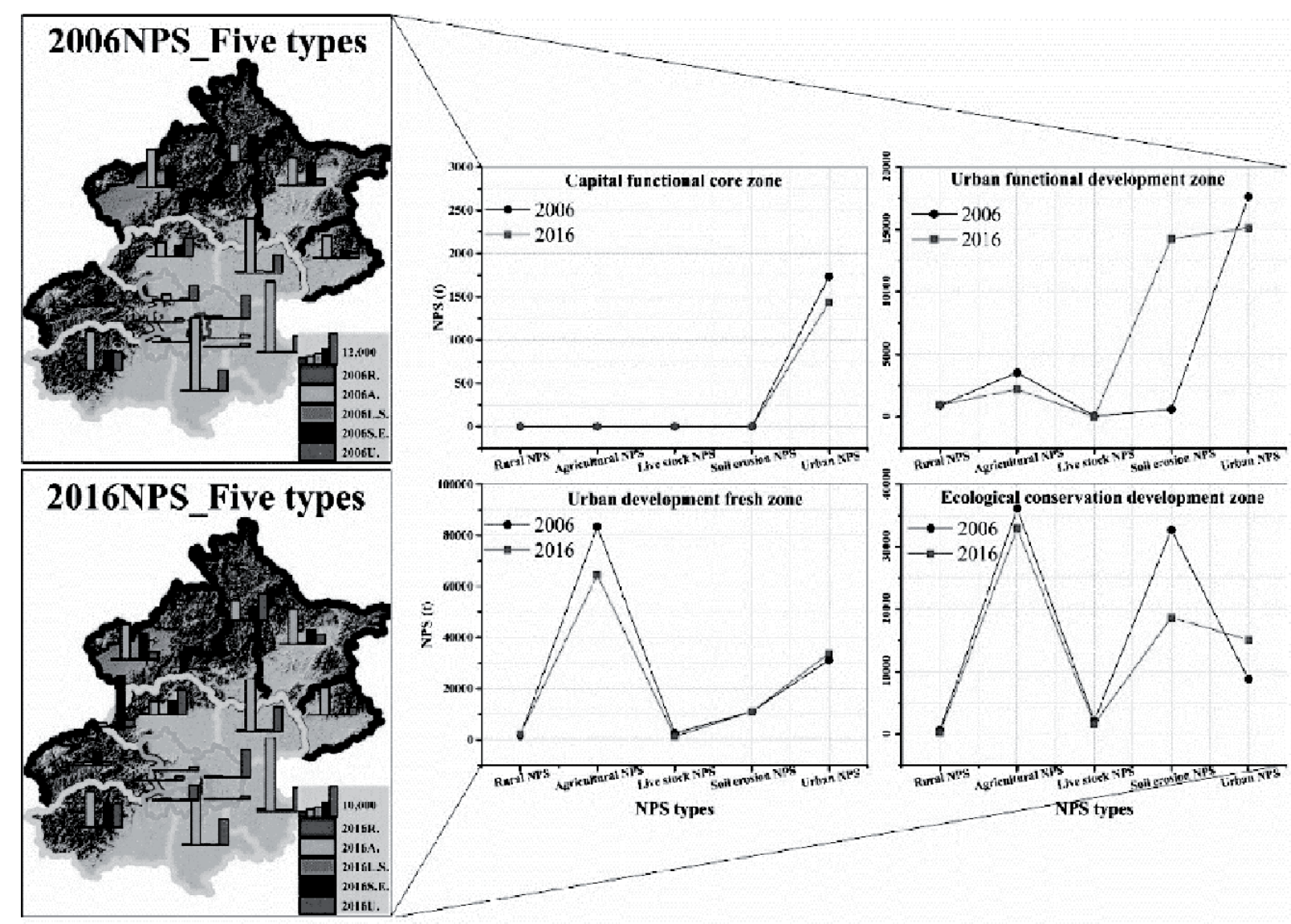

Fig. 5. Variations in the five NPSP types for the four urban function zones in Beijing from 2006 to 2016. 


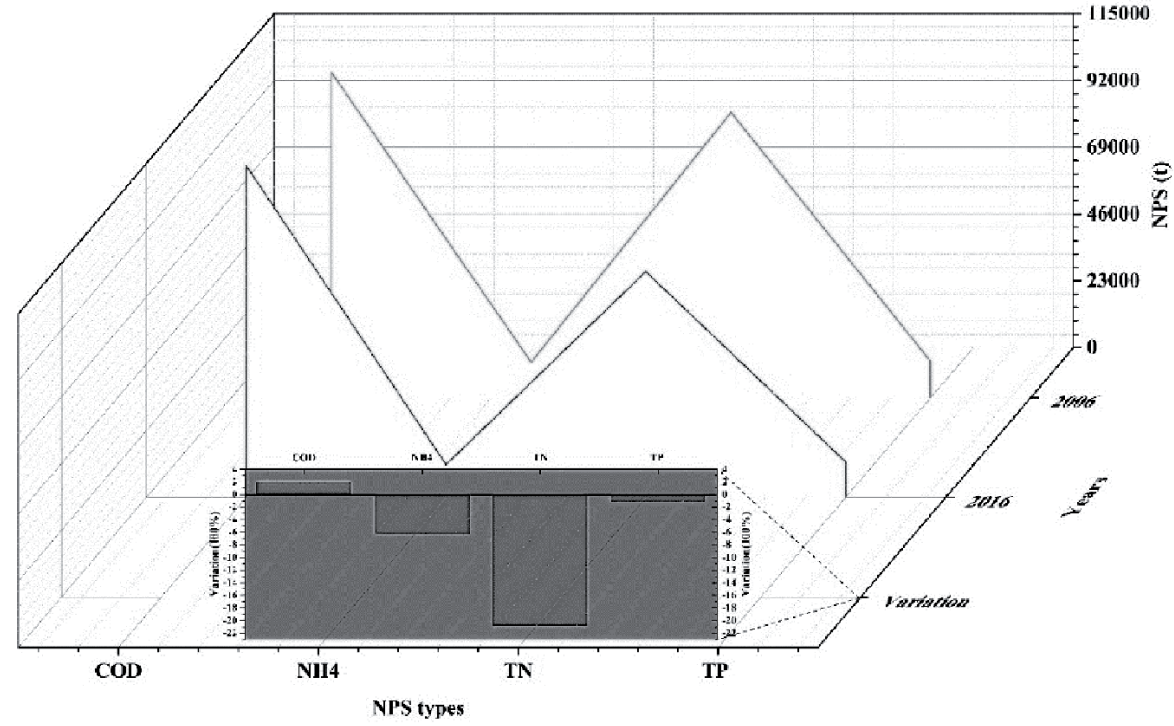

Fig. 6. Variations in four NPSP pollution elements for Beijing from 2006 to 2016.
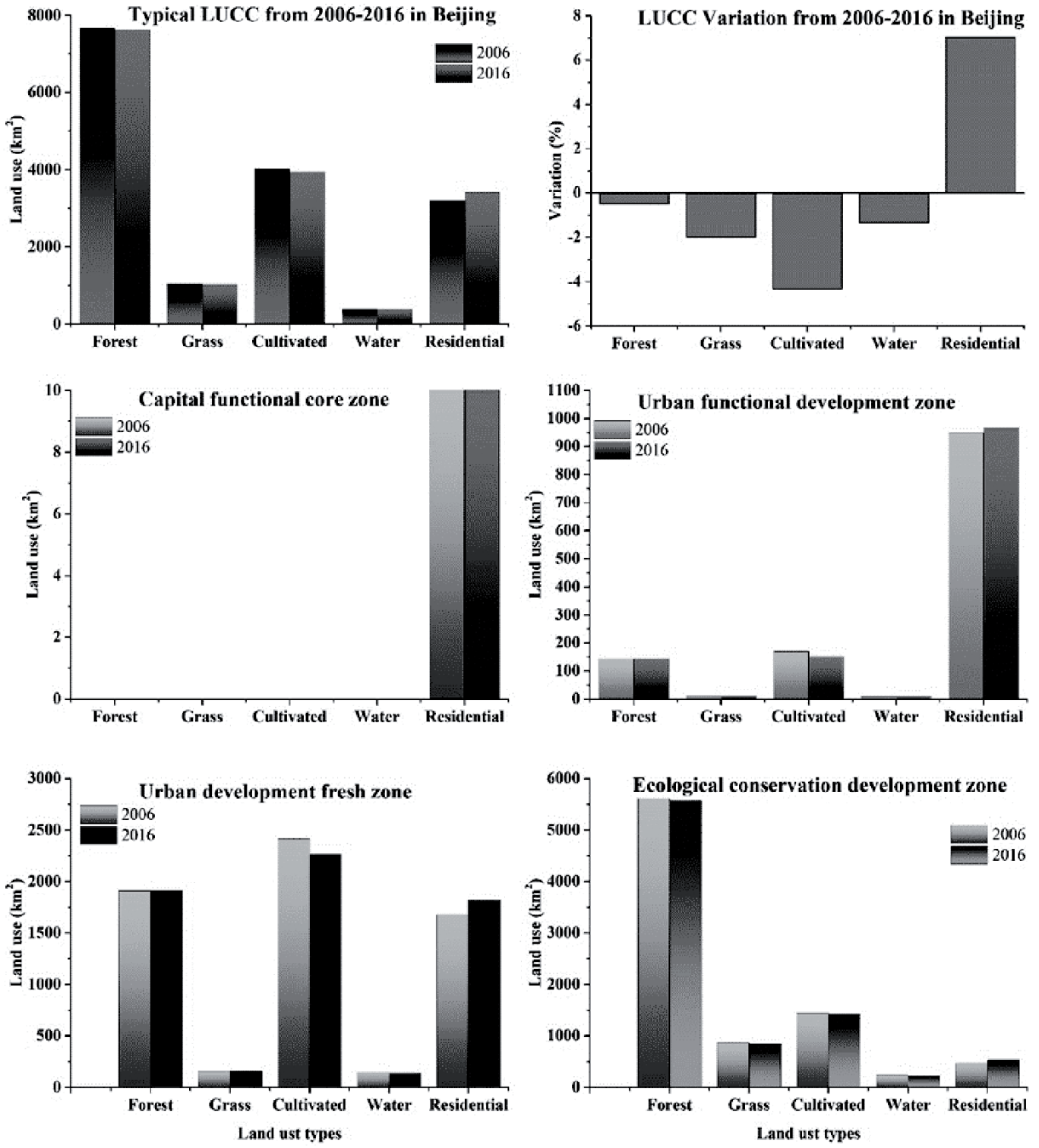

Fig. 7. Variations in LUCC for Beijing and the four zones from 2006 to 2016. 
2016, the primary variation was in the residential land, which increased by $7.05 \%$ for the total Beijing area. All the other land-use types decreased. Forest land decreased by $0.48 \%$, grassland decreased by $1.99 \%$, cultivated land decreased by $4.33 \%$, and the water body decreased by $1.34 \%$. In the capital functional core zone, residential land was the only land-use type to show no change. Five land-use types exist in the urban functional development zone. Residential land alone increased by $2.0 \%$ in the two periods, while all others decreased. In the urban development fresh zone, cultivated land decreased by $6.3 \%$ but residential land increased by $8.4 \%$. The LUCC in the ecological conservation development zone was similar to other three zones; residential land use increased by $13.6 \%$ but all others decreased.

LUCC determined the total NPSP pollution load not only in the agricultural areas but also in urban areas. LUCC influenced NPSP and amplitude both directly and indirectly. Land use associated with urban development, such as the removal of forest and grassland and replacement of pervious areas with impervious surfaces and drainage channels, changed the characteristics of the surface runoff hydrograph [35-36] and directly influenced urban NPSP contamination levels and spatial distribution patterns [37-38]. Urban NPSP has a profound influence on storm water quality due to the introduction of pollutants of physical, chemical, and biological origin, which result from anthropogenic activities [39]. The potential influence of LUCC on urban NPSP includes changes in soil characters, which are the basis for NPSP pollution release and export. In addition, NPSP remnants from previous landuse types have been released due to urban development [40-41].

Population increase and migration are significant driving forces for urban development as well as NPSP and pollution level. In this study, we surveyed total population, rural population and variations for both using the statistical yearbook (Fig. 8). Total population in Beijing during the study period increased from 11.98 million to 21.74 million, which was a $81.49 \%$ increase. In the four functional zones, total population in the capital functional core zone decreased by $5.15 \%$, and the total population in the other three functional zones (urban functional development zone, urban development fresh zone, ecological conservation development zone) increased by $103.54 \%, 141.50 \%$ and $20.66 \%$, respectively. Population in rural areas was also surveyed as an important indicator of the urbanization process. From 2006 to 2016, total rural population increased by $12.02 \%$. Rural population occurred in the three functional zones but not the capital functional core zone. In the urban functional development zone and urban development fresh zone, the rural population increased by $0.91 \%$ and $40.86 \%$, respectively. In the ecological conservation development zone, the rural population decreased by $41.48 \%$.

In our research, urban NPSP and rural NPSP increased and this was related to population size
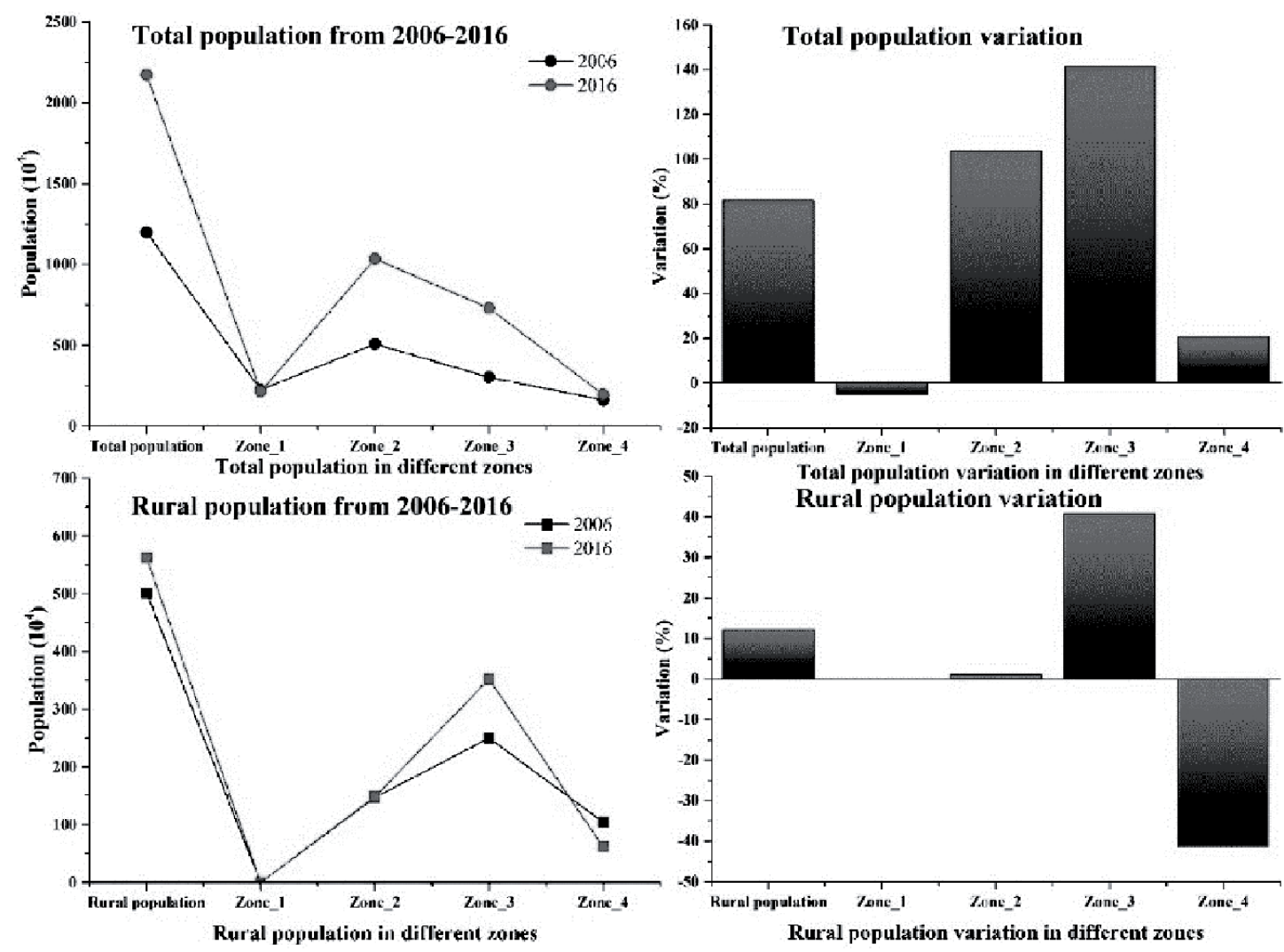

Fig. 8. Population variations for Beijing and the four zones from 2006 to 2016. 

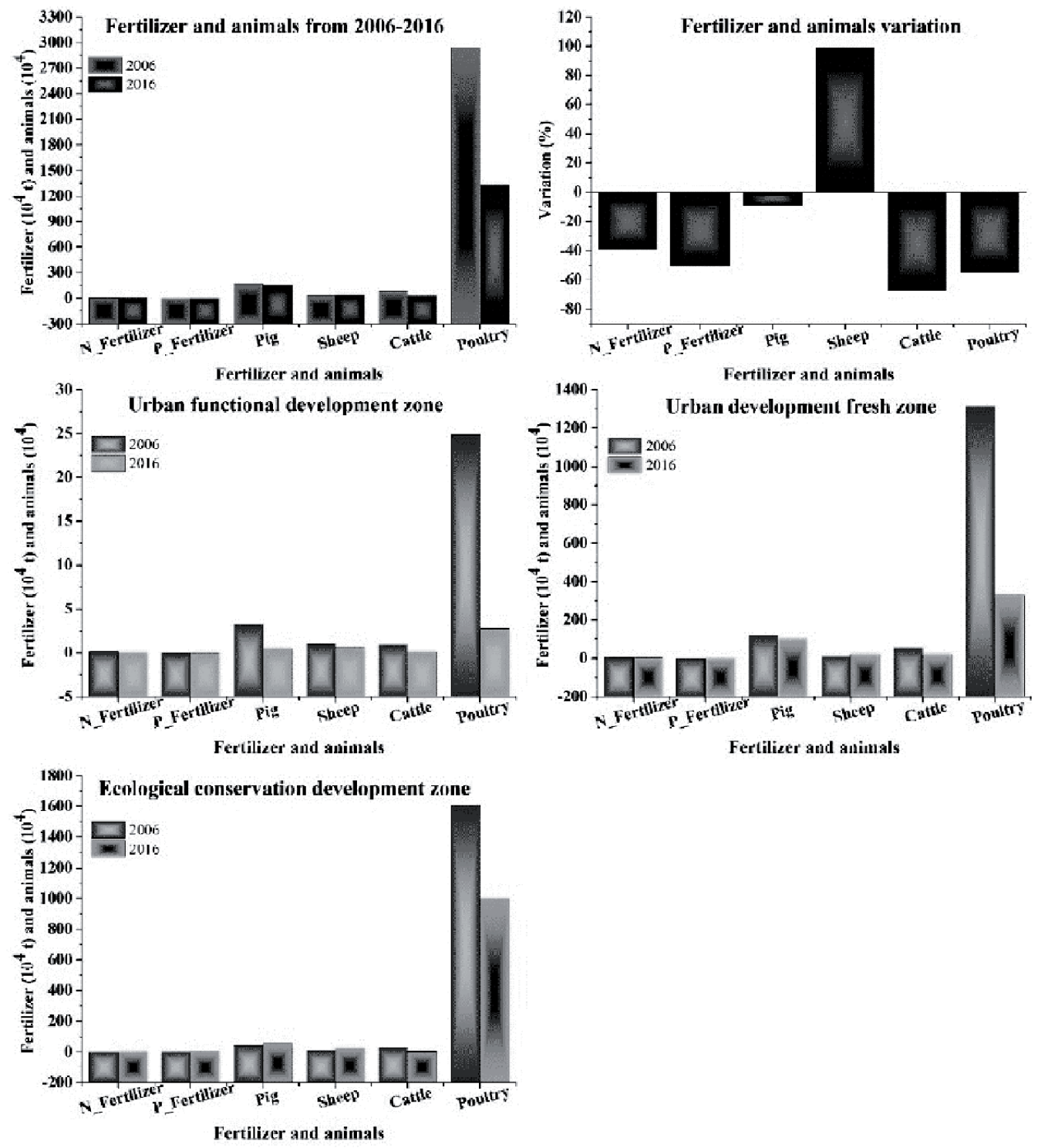

Fig. 9. Variations in agricultural production and livestock from 2006 to 2016.

(Fig. 2). In the capital functional core zone, the NPSP load decreased from 2006 to 2016 (Fig. 5). In the ecological conservation development zone, the rural NPSP decreased by $58.2 \%$ and the urban NPSP increased by $71.6 \%$ during the study period (Fig. 5). These variations in NPSP are in line with the population changes from 2006 and 2016. This indicates that population is a significant and direct driving force behind the special distribution and amount of NPSP. It is possible to explain the driving role of population from the perspective of a single person. In the pursuit of better living conditions and larger space, people have moved to developed urban and surrounding areas, and this changes the land surface for NPSP generation and transportation [42-43]. A single person is not the only unit for point source pollution but also for nonpoint source pollution [44-45]. Human activities in urban areas influence contamination elements, particularly from industrial production. This makes calculating and preventing urban NPSP more difficult [46].

\section{Urban Development and Policy Decreases NPSP from 2006 to 2016 in Beijing}

Agricultural production, including nitrogen and phosphorus fertilization and livestock production (pig, sheep, cattle, and poultry) was surveyed from 2006 to 2016 (Fig. 9). Nitrogen and phosphorus artificial fertilizer use showed similar significant declines of $38.9 \%$ and $50.4 \%$, respectively. This was the result of the reduction in cultivated land by $4.3 \%$ from 2006 to 2016. Livestock is still an important source of food for Beijing, but the total amount has declined. The pig, cattle and poultry totals decreased by $8.76 \%, 67.1 \%$ and $54.8 \%$, respectively, but sheep increased by $99.2 \%$ over the study period. Using these data, we determined that agricultural production as well as meat and poultry for Beijing declined from 2006 to 2016.

Artificial fertilization and livestock are two key NPSP sources [47-49], and they influence agricultural NPSP and livestock NPSP directly. From 2006 to 2016, 
Table 2. Data used by the model.

\begin{tabular}{|c|c|c|c|c|c|c|}
\hline Data type & Name & Source & Role & Spatial res. & $\begin{array}{l}\text { Tem. } \\
\text { res. }\end{array}$ & $\begin{array}{c}\text { Processing } \\
\text { method }\end{array}$ \\
\hline \multirow{4}{*}{ Remote sensing data } & Elevation & ASTERGDEM & Slope & $30 \mathrm{~m}$ & & CT/ENVI \\
\hline & LUCC & Landsat 8 & Landuse & $30 \mathrm{~m}$ & $16 \mathrm{~d}$ & VI/ ArcGIS \\
\hline & Vegetation cover & Landsat 8 & Model & $30 \mathrm{~m}$ & 1 month & RR/ENVI \\
\hline & Soil type & Data base & Model & $30 \mathrm{~m}$ & & CT/ENVI \\
\hline Meteorological data & Precipitation & National stations & Model & Point & 1 day & SI/ArcGIS \\
\hline \multirow{4}{*}{ Statistical data } & Population & Statistical yearbook & Model & district & 1 year & $\mathrm{SD} / \mathrm{ArcGIS}$ \\
\hline & Rural & Statistical yearbook & Model & district & 1 year & $\mathrm{SD} / \mathrm{ArcGIS}$ \\
\hline & Agricultural & Statistical yearbook & Model & district & 1 year & $\mathrm{SD} / \mathrm{ArcGIS}$ \\
\hline & Livestock & Statistical yearbook & Model & district & 1 year & $\mathrm{SD} / \mathrm{ArcGIS}$ \\
\hline \multirow{8}{*}{ Survey data } & $E_{h}$ & Prior R. & Model & - & - & Check\&SD \\
\hline & $D_{c a}$ & Prior R. & Model & - & - & Check\&SD \\
\hline & $H$ & Prior R. & Model & - & - & Check\&SD \\
\hline & $M$ & Prior R. & Model & - & - & Check\&SD \\
\hline & $B$ & Prior R. & Model & - & - & Check\&SD \\
\hline & $R_{S}$ & Prior R. & Model & - & - & Check\&SD \\
\hline & $C$ & Prior R. & Model & - & - & Check\&SD \\
\hline & $c$ & Prior R. & Model & - & - & Check\&SD \\
\hline
\end{tabular}

agricultural NPSP decreased by $19.1 \%$ and livestock NPSP decreased by $38.7 \%$ (Fig. 2), even though the amount of sheep increased. Urban development, especially in the megacity, has focused on secondary industry and the service industry [50]. Therefore, agricultural development was delayed due to it being based on natural talent and that its rate of return was lower and slower than the secondary industry and the

Table 3. Important environment policies and events held in Beijing from 2006 to 2016.

\begin{tabular}{|c|c|c|c|c|}
\hline No. & Year & Date & Important event and policy & $\begin{array}{l}\text { Role for } \\
\text { NPSP }\end{array}$ \\
\hline 1 & \multirow{4}{*}{2006} & 2006.8.1 & First China-US strategic dialogue & - \\
\hline 2 & & 2006.9 .5 & The $22^{\text {nd }}$ world congress of law & - \\
\hline 3 & & 2006.5 & The six-party talks on the nuclear issue & - \\
\hline 4 & & 2006.9.13 & 21 century forum & $\downarrow$ \\
\hline 5 & \multirow{2}{*}{2007} & 2007.1.31 & Third sustainable development education seminar. & - \\
\hline 6 & & 2007.10 .3 & The second session of the sixth round of the six-party talks & - \\
\hline 7 & \multirow{8}{*}{2008} & 2008.8 & The $29^{\text {th }}$ Olympic Games in Beijing. & $\downarrow$ \\
\hline 8 & & 2008.9.6 & Paralympic Games & $\downarrow$ \\
\hline 9 & & 2008.10 .3 & 2008 World Mind Sports Games & $\downarrow$ \\
\hline 10 & & 2008.10.16 & The sixth China international agricultural fair & - \\
\hline 11 & & 2008.10 .24 & the Seventh Asia Europe Meeting & $\downarrow$ \\
\hline 12 & & 2008.11.7 & The world health organization's first convention on traditional medicine. & $\downarrow$ \\
\hline 13 & & 2008.11.8 & China international friendship city conference. & - \\
\hline 14 & & 2008.11.11 & China Mining Congress and Expo & - \\
\hline
\end{tabular}


Table 3. Continued.

\begin{tabular}{|c|c|c|c|c|}
\hline 15 & \multirow{5}{*}{2009} & 2009.2.12 & 2009 Economic globalization and labor unions & - \\
\hline 16 & & 2009.3 & $\begin{array}{l}\text { China international energy conservation and emission reduction and new energy } \\
\text { science and technology exposition. }\end{array}$ & - \\
\hline 17 & & 2009.8 .17 & The twenty-seventh international conference on agriculture and economics. & - \\
\hline 18 & & 2009.10 .9 & World Media Summit & $\downarrow$ \\
\hline 19 & & 2009.10 .14 & The $8^{\text {th }}$ meeting of the prime ministers of the SCO member states. & - \\
\hline 20 & \multirow{4}{*}{2010} & 2010.2 .25 & 2010 Economic globalization and labor unions & - \\
\hline 21 & & 2010.5 .24 & The second round of china-us strategic and economic dialogue & - \\
\hline 22 & & 2010.8.28 & The first world war games in Beijing. & - \\
\hline 23 & & 2010.8.31 & The $17^{\text {th }}$ Beijing international book fair. & - \\
\hline 24 & \multirow{2}{*}{2011} & 2011.4 .27 & 2011 Economic globalization and labor unions & - \\
\hline 25 & & 2011.10 .5 & The first Beijing professional road cycling race. & $\downarrow$ \\
\hline 26 & \multirow{5}{*}{2012} & 2012.4 .6 & The 12th China international nuclear industry exhibition. & - \\
\hline 27 & & 2012.5 .3 & The fourth round of China-US strategic and economic dialogue & - \\
\hline 28 & & 2012.5.13 & The fifth trilateral summit meeting & - \\
\hline 29 & & 2012.6 .7 & 12th meeting of the council of heads of SCO member states & - \\
\hline 30 & & 2012.6 .7 & APEC China business leaders forum & $\downarrow$ \\
\hline 31 & \multirow{3}{*}{2013} & & "Ecological Civilization Idea" from government & $\downarrow$ \\
\hline 32 & & 2013.4 .9 & The sixth China-US Internet forum & - \\
\hline 33 & & 2013.6.28 & The third global think tank summit & - \\
\hline 34 & \multirow{5}{*}{2014} & 2014.6 .1 & International service trade fair & - \\
\hline 35 & & 2014.6.21 & Third world peace forum & - \\
\hline 36 & & 2014.7.29 & World grape conference & - \\
\hline 37 & & 2014.9.16 & United Nations millennium development goals (MDGS) & - \\
\hline 38 & & 2014.11 .10 & The $22^{\text {nd }}$ APEC economic leaders' meeting & $\downarrow$ \\
\hline 39 & \multirow{3}{*}{2015} & & "Green Development Idea" from government & $\downarrow$ \\
\hline 40 & & 2015.7.28 & Beijing world potato conference & \\
\hline 41 & & 2015.8.22 & IAAF world athletics championships & $\downarrow$ \\
\hline 42 & \multirow{2}{*}{2016} & 2016.4 .28 & Conference on cooperation and confidence-building measures in Asia & - \\
\hline 43 & & 2016.9 .10 & The thirty-ninth international organization for standardization (ISO) conference & - \\
\hline
\end{tabular}

service industry [51-52]. Agricultural NPSP plays a significant role in the total NPSP [53], and a reduction in agricultural NPSP can significantly improve environmental quality - particularly for water bodies in Beijing.

Continuous urban development and expansion have led to the transition of the megacity, and the service industry has flourished in the process. At the same time, the megacity has become an experimental area for new national policies, especially environmental policies spearheaded by a country. Between 2006 and 2016, there were 43 important events and policies implemented in Beijing (Table 3). These events included major sporting events, such as the $29^{\text {th }}$ Olympic
Games, and international meetings and forums, such as the APEC China business leaders forum. Important environmental policies include "Ecological Civilization Idea" and "Green Development Idea." These events and policies were classified into two types: common events and NPSP reduction events; policies are represented by a green arrow (Table 3).

These important events and policies have had a direct and immediate influence on NPSP load reductions in Beijing. In order to improve environmental quality, urban planning and management were utilized for these meetings and sporting events. For example, in preparation for the 29th Olympic Games, work was done in Beijing to enhance environmental quality 
(e.g., rain, dirt separation), improve the urban living environment (e.g., shantytowns transformation), and to promote the city image [54-55]. These major events and policies drove urban development in the short-term and changed land surface conditions as well as NPSP loading [56]. The characteristics of NPSP loading and prevention in a megacity are very different from NPSP pollution in an agricultural watershed [57]. NPSP in a megacity requires more attention in terms of the role of environmental policies.

\section{Conclusions}

This work examined variations in and the spatial distribution of five NPSP types (rural NPSP, agricultural NPSP, livestock NPSP, soil erosion NPSP and urban NPSP) and four pollution elements (COD, $\mathrm{NH}_{4}, \mathrm{TN}$ and TP). Our research focused on Beijing, which represented a typical developing megacity, from 2006 to 2016. For our calculations, we used a model set of export coefficients and statistical models. The NPSP load and spatial distribution were also analyzed in the four city functional zones.

Our results indicate that the total NPSP amount in a single year varied from $234,700 \mathrm{t}$ in 2006 to 215,709 $\mathrm{t}$ in 2016, representing a decrease of $8.1 \%$. For the five NPSP types, agricultural NPSP was the primary NPSP source and measured $46.2 \%$ in 2016. Agricultural NPSP, livestock NPSP and soil erosion NPSP decreased by $19.1 \%, 38.7 \%$, and $0.8 \%$, respectively. Urban NPSP and rural NPSP increased by $10.8 \%$ and $8.5 \%$, respectively. The spatial distribution of the five NPSP types did not demonstrate significant variations from 2006 to 2016, except in the case of urban NPSP. In the four functional zones, urban NPSP was the only type in the capital function core zone where the total NPSP load decreased (by 17.3\%) from 2006 to 2016. In the urban functional development zone, the total NPSP increased by about $43.0 \%$, in the urban development fresh zone, the total NPSP load decreased by $13.1 \%$, and in the ecological conservation development zone, the total NPSP load decreased by $14.7 \%$. The urban functional development zone was key to preventing NPSP in a developing megacity.

The driving forces behinds the NPSP variation in the megacity included urban development, population increase and migration, as well as policy and the role of urban transformation. Urban development led to land-use and land-cover changes and this influenced the NPSP load in the megacity. Population increase and migration had a direct impact on urban NPSP and rural NPSP at the megacity scale by increasing $\mathrm{P}$ loading into the environment. Urban development reduced agricultural production and the related NPSP loading. Policy and the role of urban transformation caused the NPSP load to decrease in the short-term in the megacity. Our research analyzed variations in multi-source NPSP types in the megacity on a long-term timescale and addressed the question of what drives these variations. This information not only has new implications for the law of NPSP on a megacity scale, but also helps managers make better policies regarding urban planning and NPSP prevention in a developing megacity.

\section{Acknowledgements}

We acknowledge all of the editors and reviewers for their valuable advices. The authors would also like to thank the financial support from the National Natural Science Foundation of China (Grant Nos. 41801334, U1812401, U1603241), the financial support from the China Postdoctoral Science Foundation (2017M620663), the Fundamental Research Funds for the Central Universities (2017NT11), the National Key Project for R\&D (2018YFC0407900), and National Young Scientist Natural Science Foundation of China (41601569). We thank Kara Bogus for editing the English text of a draft of this manuscript.

\section{Conflict of Interest}

The authors declare no conflict of interest.

\section{References}

1. CARPENTER S.R., CARACO N.F., CORRELL D.L., HOWARTH R.W., SHARPLEY A.N., SMITH V.H. Nonpoint pollution of surface waters with phosphorus and nitrogen. Ecological Applications. 8 (3), 559, 1998.

2. SHARPLEY A.N., JARVIE H.P. Agricultural management, water quality \& ecology: Putting practice into policy. National Agricultural Biotechnology Council Conference Proceedings. 24, 87, 2012.

3. LOU H., YANG S., ZHAO C., SHI L., WU L., WANG Y., WANG Z. Detecting and analyzing soil phosphorus loss associated with critical source areas using a remote sensing approach. Science of the Total Environment. 573, 397, 2016.

4. YUAN Z., JIANG S., SHENG H., LIU X., HUA H., LIU X., ZHANG Y. Human Perturbation of the Global Phosphorus Cycle: Changes and Consequences. Environmental science \& technology. 52 (5), 2438, 2018.

5. TSIHRINTZIS V.A., HAMID R. Modeling and management of urban stormwater runoff quality: a review. Water Resources Management. 11 (2), 136, 1997.

6. MA X., LI Y., ZHANG M., ZHENG F., DU S. Assessment and analysis of non-point source nitrogen and phosphorus loads in the three gorges reservoir area of hubei province, china. Science of the Total Environment. 412 (412-413), 154, 2011.

7. WHITE R.R., HALL M.B. Nutritional and greenhouse gas impacts of removing animals from us agriculture:. Proceedings of the National Academy of Sciences of the United States of America. 114 (48), E10301-E10308, 2017.

8. CHEN T., LIU X., ZHU M., ZHAO K., WU J., XU J., HUANG P. Identification of trace element sources and associated risk assessment in vegetable soils of the urban- 
rural transitional area of Hangzhou, China. Environmental Pollution. 151 (1), 67, 2008.

9. ANACHE J., FLANAGAN D.C., SRIVASTAVA A., WENDLAND E.C. Land use and climate change impacts on runoff and soil erosion at the hillslope scale in the braziliancerrado. Science of the Total Environment. 622623, 140, 2017

10. ZHANG H., SHAN B. Historical distribution and partitioning of phosphorus in sediments in an agricultural watershed in the Yangtze-Huaihe region, China. Environmental science \& technology. 42 (7), 2328, 2008.

11. ALMARAZ M., BAI E., WANG C., TROUSDELL J., CONLEY S., FALOONA I., HOULTON B. Z. Agriculture is a major source of NOx pollution in California. Science advances. 4 (1), eaao3477, 2018.

12. TSIHRINTZIS V.A., HAMID R. Runoff quality prediction from small urban catchments using swmm. Hydrological Processes. 12 (2), 311, 1998.

13. LOU H., YANG S., ZHAO C., WANG Z., SHI L., WU L., DONG G., CAI M., HAO F., SUN Y. Using a nitrogenphosphorus ratio to identify phosphorus risk factors and their spatial heterogeneity in an intensive agricultural area. Catena. 149, 426, 2017

14. WANG Q., LIU R., MEN C., GUO L. Application of genetic algorithm to land use optimization for non-point source pollution control based on clue-s and swat. Journal of Hydrology. 560, 2018.

15. JOHNSON R.C., JIN H.S., CARREIRO M.M., JACK J.D. Macroinvertebrate community structure, secondary production and trophic-level dynamics in urban streams affected by non-point-source pollution. Freshwater Biology. 58 (5), 843, 2013.

16. WANG M., MA L., STROKAL M., MA W., LIU X., KROEZE C. Hotspots for nitrogen and phosphorus losses from food production in china: a county-scale analysis. Environmental Science \& Technology. 52 (10), 5782, 2018.

17. LEYK S., UHL J. H., BALK D., JONES B. Assessing the accuracy of multi-temporal built-up land layers across rural-urban trajectories in the united states. Remote Sensing of Environment. 204, 898, 2018.

18. LIN C., MA R., XIONG J. Can the watershed nonpoint phosphorus pollution be interpreted by critical soil properties? a new insight of different soil p states. Science of the Total Environment. 628, 2018

19. VENTURA S.J., KIM K. Modeling urban nonpoint source pollution with a geographic information system. Jawra Journal of the American Water Resources Association. 29 (2), 189, 1993.

20. MITCHELL G. Mapping hazard from urban non-point pollution: a screening model to support sustainable urban drainage planning. Journal of Environmental Management. 74 (1), 1, 2005.

21. PING Z., LIU Y., YING P., YU Z. Land use pattern optimization based on clue-s and swat models for agricultural non-point source pollution control. Mathematical \& Computer Modelling. 58 (3-4), 588, 2013.

22. BURGES S.J., LETTENMAIER D.P. Probabilistic methods in stream quality management [J]. Water Resources Bulletin. 11 (1), 115-, 1975.

23. ALEXANDER R.B., ELLIOTT A.H., SHANKAR U., MCBRIDE G.B. Estimating the sources and transport of nutrients in the waikato river basin, new zealand. Water Resources Research. 38 (12), 4-1-4-23, 2002.
24. JOHNES P.J. Evaluation and management of the impact of land use change on the nitrogen and phosphorus load delivered to surface waters: the export coefficient modelling approach. Journal of Hydrology. 183 (3-4), 323, 1996.

25. ROSSMAN L.A. Storm water management model user's manual. USA: United States Environmental Protection Agency, 2009.

26. WHITTEMORE RC. The BASINS model. Water Environment and Technology. 10 (12), 57, 1998.

27. MENG Q., ZHANG L., SUN Z., MENG F., WANG L., SUN Y. Characterizing spatial and temporal trends of surface urban heat island effect in an urban main builtup area: A 12-year case study in Beijing, China. Remote Sensing of Environment. 204, 826, 2018.

28. LI F., WANG R., PAULUSSEN J., LIU X. Comprehensive concept planning of urban greening based on ecological principles: a case study in Beijing, China. Landscape and urban planning. 72 (4), 325, 2005.

29. Beijing Municipal Statistical Bureau. Beijing Statistical Yearbook. China Statistics Press, Beijing 2017 [In Chinese].

30. LI X., ZHOU W., OUYANG Z. Forty years of urban expansion in Beijing: what is the relative importance of physical, socioeconomic, and neighborhood factors? Applied Geography. 38, 1, 2013.

31. JONES C.A., COLE C.V., SHARPLEY A.N., WILLIAMS J.R.A simplified soil and plant phosphorus model: I. Documentation. Soil Science Society of America Journal. 48 (4), 800, 1984.

32. SHEN Z.Y., HOU X.S., LI W., AINI G. Relating landscape characteristics to non-point source pollution in a typical urbanized watershed, Beijing. Landscape and Urban Planning. 213, 96, 2014

33. SHEN Z.Y., HOU X.S., LI W., AINI G., CHEN L., GONG Y.W. Impact evaluation of landscape patterns at multiple spatial scales on water quality: a case study in a typical urbanized watershed, China. Ecological Indicators. 48, 417, 2015.

34. BARCO J., WONG K. M., STENSTROM M. K. Automatic calibration of the US EPA SWMM model for a large urban catchment. Journal of Hydraulic Engineering. 134 (4), 466, 2008.

35. GOONETILLEKE A., THOMAS E., GINN S., GILBERT D. Understanding the role of land use in urban stormwater quality management. Journal of Environmental Management. 74 (1), 31, 2005.

36. JHA R., OJHA C.S.P., BHATIA K.K.S. Non-point source pollution estimation using a modified approach. Hydrological Processes. 21 (8), 1098, 2010.

37. SHARPLEY A. N., BERGSTRÖM L., ARONSSON H., BECHMANN M., BOLSTER C. H., BÖRLING K., DJODJIC F., JARVIE H., SCHOUMANS O., STAMM C., TONDERSKI K. S., ULÉN B., UUSITALO R., WITHERS P. Future agriculture with minimized phosphorus losses to waters: Research needs and direction. Ambio. 44 (2), 163, 2015.

38. LOU H., ZHAO C., YANG S., SHI L., WANG Y., REN X., BAI J. Quantitative evaluation of legacy phosphorus and its spatial distribution. Journal of environmental management. 211, 296, 2018.

39. YANG S., BAI J., ZHAO C., LOU H., WANG Z., GUAN Y., ZHANG Y., ZHANG C., YU X. Decline of N and $\mathrm{P}$ Uptake in the Inner Protection Zone of a Terminal Reservoir during Inter-Basin Water Transfers. Water. 10 (2), 178, 2018. 
40. JONES K.R., VENTER O., FULLER R.A., ALLAN J.R., MAXWELL S.L., NEGRET P.J., WATSON J.E. One-third of global protected land is under intense human pressure. Science. 360 (6390), 788, 2018.

41. SHARPLEY A.N., KLEINMAN P.J., FLATEN D.N., BUDA A.R. Critical source area management of agricultural phosphorus: experiences, challenges and opportunities. Water Science and Technology. 64 (4), 945, 2011.

42. WANG X., WANG Q., YANG S., ZHENG D., WU C., MANNAERTS C. M. Evaluating nitrogen removal by vegetation uptake using satellite image time series in riparian catchments. Science of The Total Environment. 409 (13), 2567, 2011.

43. GONZÁLEZ-ROGLICH M, SWENSON J.J. Tree cover and carbon mapping of Argentine savannas: Scaling from field to region. Remote Sensing of Environment. 172, 139, 2016.

44. JIANG S., YUAN Z. Phosphorus Flow Patterns in the Chaohu Watershed from 1978 to 2012. Environmental science \& technology. 49 (24), 13973, 2015.

45. KUMAR R., LIVNEH B., SAMANIEGO L. Toward computationally efficient large-scale hydrologic predictions with a multiscale regionalization scheme. Water Resources Research. 49 (9), 5700, 2013.

46. LIU J., HU Y., YANG J., ABDI D., CADE-MENUN B.J. Investigation of soil legacy phosphorus transformation in long-term agricultural fields using sequential fractionation, $\mathrm{P}$ K-edge XANES and solution P NMR spectroscopy. Environmental science \& technology. 49 (1), 168, 2014.

47. NIJLAND W., BOLTON D.K., COOPS N.C., STENHOUSE G. Imaging phenology; scaling from camera plots to landscapes. Remote Sensing of Environment. 177, 13, 2016.

48. RODRIGUES M., PAVINATO P.S., WITHERS P.J.A., TELES A.P.B., HERRERA W.F.B. Legacy phosphorus and no tillage agriculture in tropical oxisols of the Brazilian savanna. Science of The Total Environment. 542, 1050, 2016.

49. SATTARI S.Z., BOUWMAN A.F., GILLER K.E., VAN ITTERSUM M.K. Residual soil phosphorus as the missing piece in the global phosphorus crisis puzzle. Proceedings of the National Academy of Sciences. 109 (16), 6348, 2012.

50. SATTARI S.Z., VAN ITTERSUM M.K., GILLER K.E., ZHANG F., BOUWMAN A.F. Key role of China and its agriculture in global sustainable phosphorus management. Environmental Research Letters. 9 (5), 054003, 2014.

51. SCHOLZ R.W., HELLUMS D.T., ROY A.A. Global sustainable phosphorus management: a transdisciplinary venture. CURRENT SCIENCE. 108 (7), 1237, 2015.

52. SCHOUMANS O. F., BOURAOUI F., KABBE C., OENEMA O., VAN DIJK K.C. Phosphorus management in Europe in a changing world. Ambio. 44 (2), 180, 2015.

53. CAMPBELL S. Green cities, growing cities, just cities?: Urban planning and the contradictions of sustainable development. Journal of the American Planning Association. 62 (3), 296, 1996.

54. KAISER E.J., GODSCHALK D.R., CHAPIN F.S. Urban land use planning (Vol. 4). Urbana, IL: University of Illinois Press. 1995.

55. SHEN Z., LIAO Q., HONG Q., GONG Y. An overview of research on agricultural non-point source pollution modelling in China. Separation and Purification Technology. 84, 104, 2012.

56. WANG T., XIE S. Assessment of traffic-related air pollution in the urban streets before and during the 2008 Beijing Olympic Games traffic control period. Atmospheric Environment. 43 (35), 5682, 2009.

57. ZHOU Y., AP J. Residents' perceptions towards the impacts of the Beijing 2008 Olympic Games. Journal of Travel Research. 48 (1), 78, 2009. 
